\title{
Molecular epidemiology of hepatitis C virus genotypes and subtypes among injecting drug users in Hungary
}

B Tresó ${ }^{1}$, M Takács¹, Á Dencs ${ }^{1}$, M Dudás², A Pár³, E Rusvai (rusvai.erzsebet@oek.antsz.hu)1

1. Division of Virology, National Center for Epidemiology, Budapest, Hungary

2. Department of Communicable Diseases, National Center for Epidemiology, Budapest, Hungary

3. First Department of Internal Medicine, Medical School, University of Pécs, Pécs, Hungary

Citation style for this article:

Tresó B, Takács M, Dencs Á, Dudás M, Pár A, Rusvai E. Molecular epidemiology of hepatitis C virus genotypes and subtypes among injecting drug users in Hungary. Euro Surveill. 2013;18(47):pii=20639. Available online: http://www.eurosurveillance.org/ViewArticle.aspx?Articleld=20639

Article submitted on 04 December 2012 / published on 21 November 2013

The aim of this study was to determine the geographical distribution of hepatitis $C$ virus genotypes/subtypes among people who inject drugs (PWID) recruited at 22 needle exchange sites and drug outpatient services in all seven Planning and Statistical Regions of Hungary. Of 198 such PWID, 147 (74.2\%), 45 (22.7\%) and six $(3.0 \%)$ carried genotype 1,3 or 4 , respectively, and $31(72.1 \%)$ of the 43 genotype 1 sequences were of subtype 1a. Genotype 3 was significantly more prevalent in provincial towns than in the capital, Budapest. Injecting for a longer period and an older age both correlated with a higher prevalence of genotype 3, suggesting possible future changes in genotype distribution. The distributions of hepatitis $C$ virus genotypes/subtypes differed significantly between the tested PWID and the general population. The identification of genotype 3 reflected its worldwide occurrence among PWID. Our results underline the importance of genotyping before treatment, especially among people who have ever injected drugs in Hungary.

\section{Introduction}

The hepatitis C virus (HCV) may rarely cause symptomatic acute hepatitis. The infection becomes persistent in ca. $85 \%$ of these cases, and its persistence may be responsible for liver cirrhosis, end-stage liver disease and hepatocellular carcinoma. HCV has been suggested to have six genotypes, which differ from each other by $31-33 \%$ at the nucleotide level and are further classified into several subtypes [1]. These genotypes have different susceptibility to treatment [2]. Each genotype and subtype exhibits a certain geographical distribution, e.g. genotypes 1,2 and 3 occur virtually worldwide. On the American continent subtype $1 \mathrm{a}$ is the most prevalent, in Europe it is subtype 1b. Genotype 4 is mainly present in North and Central Africa and in the Middle East [3]. Genotype 3 originates from Asia, but subtype $3 a$ is widely distributed among people who inject drugs (PWID) around the world [4]. In Hungary, subtype $1 \mathrm{~b}$ has been reported in $85 \%$, subtype $1 \mathrm{a}$ in $4.5 \%$, and genotype 3 in $0.5 \%$ of chronic HCV carriers among the general population, with mixed infections in the remainder [5]. A similar genotype distribution, but without mixed infections, has been observed in southern Hungary [6].

Since the screening of blood products for HCV was introduced in Europe in the 1990s, HCV transmission has become closely associated with the sharing of injection equipment among PWID [7]. In Hungary, 126 acute HCV cases were reported to the National Center for Epidemiology (NCE) from 2006 to 2010. In 72 cases, the epidemiological investigations revealed potential risk factors, and injection drug use was reported in 20 of these patients $[8,9]$. The seroprevalence of HCV among PWID is high $(22.6 \%$ in 2008$)$ relative to similar age groups in the general population $(<1 \%)[10,11]$.

No data are available on HCV genotypes in Hungarian PWID. The aims of the present study were therefore to determine the genotype and subtype distributions in this group, to predict possible changes in such distributions, and to examine the phylogenetic relatedness of the HCV sequences.

\section{Methods}

\section{Patients and samples}

From 2006 to 2011, capillary blood samples were collected through the use of self-retracting single-use lancets from 2,133 PWID appearing at 22 needle exchange sites and drug outpatient services in all seven Planning and Statistical Regions of Hungary(Central and Western Transdanubial Regions were underrepresented relative to their inhabitants). Participation was voluntary; a meal ticket was offered to motivate contribution. The samples were dried on Guthrie cards (Macherey-Nagel $\mathrm{GmbH}$ ), and sent to the NCE. The dried blood spots (DBSs) were stored at $20{ }^{\circ} \mathrm{C}$ until analysis. From PWID who donated multiple samples during the study period, only one sample was included in the analysis. As a comparison group (referred to as the general population), 89 treatment-naïve HCV carriers seen by hepatologists were randomly selected between 2006 and 
2011from all Statistical Regions of the country (evenly represented relative to PCR-positive PWID).

This study was approved by the Ethics Committee of the NCE.

\section{Serology}

Each DBS, cut out for serology, was placed into 200 $\mu \mathrm{l}$ of PBS containing $0.05 \%$ TWEEN 20 and $0.08 \%$ $\mathrm{Na}$-azide, vortexed and eluted overnight at $4{ }^{\circ} \mathrm{C}$. For anti-HCV antibody detection, HCV Ab (Dia.Pro) ELISA was used. The results were confirmed by Innotest HCV Ab IV ELISA or HCV Inno-LIA (Innogenetics).

\section{Questionnaire}

After informed consent had been obtained from the PWID, they voluntarily completed anonymous questionnaires on risk behaviour relating to the transmission of $\mathrm{HCV}$, with the help of trained social workers. The questionnaire had been compiled on the basis of the recommendations of the European Monitoring Centre for Drugs and Drug Addiction. The determined genotype/ subtype was linked to the corresponding questionnaire through a unique anonymous identification code.

Detection of HCV RNA, sequencing, genotyping and subtyping Each DBS was placed into $500 \mu \mathrm{l}$ of TRI REAGENT BD (Sigma), $166 \mu$ l of RNase/ DNase-free water (Gibco) and $14 \mu \mathrm{l}$ of $5 \mathrm{~N}$ acetic acid (Reanal). Tubes were vortexed, and incubated for $1 \mathrm{~h}$ at room temperature. Further steps were carried out according to the Sigma instructions. Pellets were dissolved in $8 \mu \mathrm{l}$ of water and subjected to reverse transcription through the use of a GeneAmp RNA PCR kit with random hexamers (Applied Biosystems). The protocol was modified: the final concentration of each dNTP was $0.4 \mathrm{mM}$. The presence of HCV RNA was determined by a previously reported nested PCR, which detects all known genotypes with primers specific for the 5'UTR [12]. PCR products were purified and directly sequenced as described earlier [12]. HCV subtyping was carried out via Line Probe Assay (LIPA; Siemens Versant HCV Genotype 2.0 Assay).

\section{Phylogenetic analysis}

For the analysis of the $\mathrm{NS}_{5} \mathrm{~B}$ coding region of genotype 3 viruses, the published primers [13] were modified as follows:

- $\mathrm{HCV}_{3}$ a outer sense: 8,504-8,527 (5'ACAATCACTTGTTACATCAARGCC),

- HCV3a outer antisense: 9,051-9,072 (5'TCTACTGGAGAGTAACTGTGGA),

- $\mathrm{HCV}_{3}$ a inner sense: 8,556-8,575 (5'GGRACCCGGACTTTCTTGTC),

- $\mathrm{HCV}_{3}$ a inner antisense: 9,012-9,033 (5'CCATGGAGTCTTTCAATGATTG).

The PCR conditions were not changed [13]. The products were purified and directly sequenced [12]. $\mathrm{NS}_{5} \mathrm{~B}$ nucleotide sequences obtained from PWID have been deposited in GenBank (accession numbers JQ821321JQ821345). These and other sequences from 11 countries were analysed and phylogenetic trees were constructed as described earlier [12], with the difference that the Jukes-Cantor model was selected, and subtype 3 b isolate (accession number D49374) was used as an outgroup.

Statistical analysis

All analyses were conducted using STATA 11 software (StataCorp. 2010. Stat Statistical Software: Release 11. College Station, TX: StataCorp LP).

Baseline characteristics of study participants (age, sex, geographical distribution, duration of drug use, type of drug) and HCV genotypes and subtypes were compared using the chi-squared test or Fisher's exact test, as appropriate. Association between injecting drug use and HCV genotype/subtype was assessed by computing crude odds ratios (ORs). Bivariable analysis was performed by using the Mantel-Haenszel summary chi-squared statistics to further explore any potential confounding effect. Effect modification was assessed by comparing ORs across the strata, and by the use of the test of homogeneity. A multivariable logistic regression model was used to determine the adjusted odds ratios (AOR) with 95\% confidence interval $(\mathrm{Cl})$. In the statistical analysis, a $p$ value of $<0.05$ was considered indicative of a significant difference.

\section{Results}

Of the 2,133 PWID tested, 509 proved to be positive for anti-HCV antibodies. Viral RNA was detected in 211 (65\%) of $323 \mathrm{HCV}$ antibody-positive samples that were available for PCR analysis. RNA-positive samples were obtained in six of the seven Regions. For 198 of the 211 PCR-positive samples conclusive genotyping results were obtained. Among those 198 PWID, 74.2\% $(n=147)$ were infected with genotype $1,22.7 \%(n=45)$ with genotype 3 , and $3.0 \%(n=6)$ with genotype 4 . Of the 89 HCV RNA-positive patients from the general population sample, $96.6 \%(n=86), 2.2 \%(n=2)$ and $1.1 \%(n=1)$ carried genotype 1,3 or 4 , respectively (Figure, panel A). The prevalence of genotype 3 among PWID was significantly higher than in the general population ( $p<0.001$ ). The frequency of genotype 1 was significantly lower (p<0.001) among PWID, while that of genotype 4 was similar in both groups.

Subtyping was performed for 91 samples from PWID. The HCV subtype was identified in 79 samples, in six cases the assay did not reveal precisely whether genotype 1 or 6 was present, and all of the six genotype 4 viruses were genotypable, but not subtypable with LIPA.

Of the 147 samples from PWID with HCV genotype 1, 43 were subtyped: 31 were found to be of subtype $1 \mathrm{a}$, and 12 of subtype $1 \mathrm{~b}$, with no significant geographical difference in subtype distribution between the capital and elsewhere. In the general population, three subtype $1 \mathrm{a}$ 
Distribution of hepatitis $\mathrm{C}$ virus genotypes (A) and subtypes of genotype 1 (B) among people who inject drugs and the general population, Hungary, 2006-2011
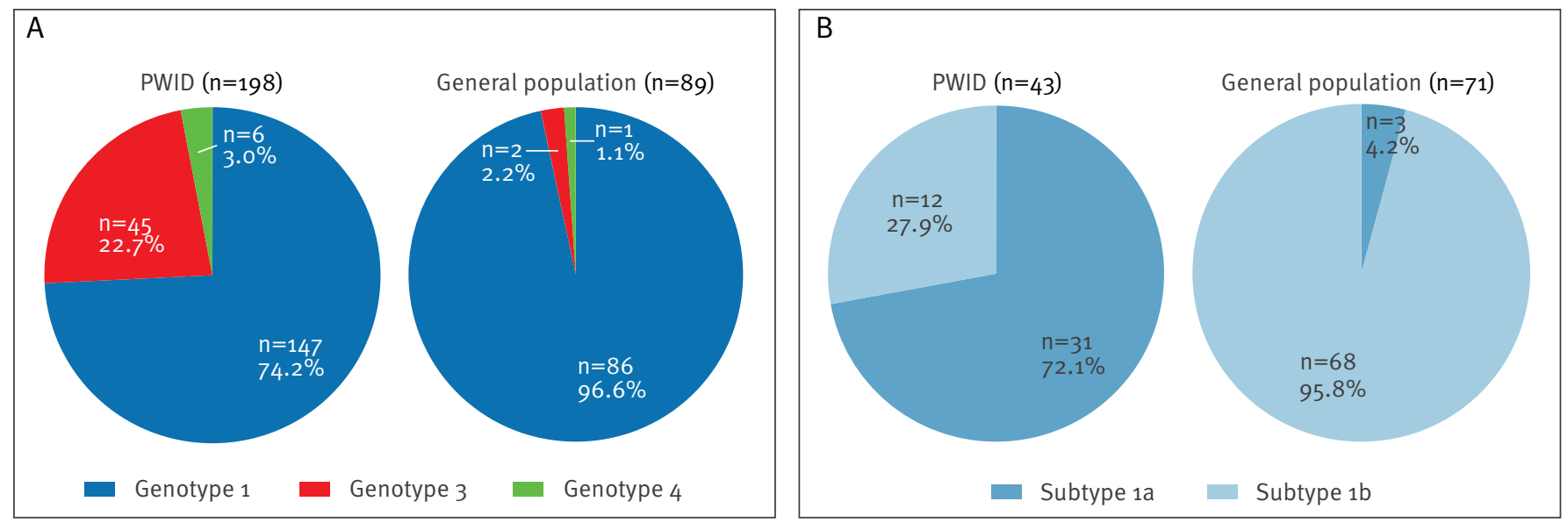

PWID: people who inject drugs.

and 68 subtype $1 \mathrm{~b}$ viruses were detected, again with no significant difference between Budapest and elsewhere. Subtype 1a was significantly more frequent among PWID than in the general population ( $p<0.001$, Figure, panel B). Of the 45 genotype 3 viruses detected in PWID, 36 were subtyped, and all were of subtype $3 a$. Genotype 3 was significantly more prevalent in the provincial towns ( $p<0.001)$.

Genotype 3 was significantly more prevalent among those who had been injecting drug for a longer period of more than five years or belonged to older age groups (25-34 and $>34$ years), than among those who had started injecting more recently (less than five years before testing) or belonged to younger age groups (Table).

After data were adjusted to age and geographical distribution, the difference in the prevalence of genotype 3 HCV remained significant between PWID and the general population ( $p<0.001, A O R: 52.88,95 \% \mathrm{Cl}$ : 11.21-249.39). Multivariable logistic regression confirmed that among PWID, genotype 3 were significantly more prevalent in provincial towns than in Budapest after the data were adjusted to age ( $\leq 34$ or $>34$ years) and duration of drug use (p<0.001, AOR: $0.22,95 \% \mathrm{Cl}$ : $0.10-0.47)$.

A correlation was observed between the HCV genotype and the type of drug injected (opiate: $n=145$, other: $n=47$, unknown: $n=6$ ). Genotype 3 was significantly associated with opiate drug use (39/145 versus 5/47, $p=0.022$ ), although after adjusting the data to the duration of injection drug use and geographical distribution, the assumed difference was not confirmed $(p=0.053$, AOR: 3.22 95\% Cl: 0.99-10.54).
Phlyogenetic analysis of the $\mathrm{NS}_{5} \mathrm{~B}$ regions revealed that the HCV genotype 3 sequences of Hungarian PWID did not form a separate clade, but certain sequences were grouped together, forming at least three subclusters (data not shown).

\section{Discussion}

This study has furnished the first data on the HCV genotype and subtype distributions among PWID in Hungary. Approximately one third (2,133 individuals) of the estimated population of Hungarian PWID [8] was examined. We consider these individuals as representative of the overall population of PWID in Hungary. We used DBS, which can also be collected by trained social workers. The willingness to donate DBS is better than in the case of venous puncture [14]; moreover, it permits large-scale field studies because sample storage and transportation do not require a special infrastructure [15]. In agreement with other authors [16,17], we have demonstrated that DBSs samples are suitable for molecular epidemiological investigations of HCV in the population of PWID. The use of DBSs has the limitation that some samples may give false-negative results [18], but this is not likely to have a significant influence on the genotype and subtype prevalence data.

The genotype and subtype distributions of HCV were found to differ between PWID and the general population. The abundance of genotype 3 and subtype $1 \mathrm{a}$ among PWID was in accordance with data on PWID in industrialised nations worldwide [4,19-22]. Since genotype 3 and subtype $1 a$ are rare in the general Hungarian population $[5,6]$, we assume that Hungary is involved in the worldwide epidemic of these genotypes among PWID, and that genotype 3 and subtype $1 \mathrm{a}$ may possibly have entered the Hungarian population of PWID from abroad. Genotype 3 proved to be significantly more frequent among PWID who entered the study in 
Prevalence of hepatitis C virus genotypes among people who inject drugs, by age and duration of drug use, Hungary, 2006$2011(n=198)$

\begin{tabular}{|c|c|c|c|}
\hline \multirow{2}{*}{$\begin{array}{l}\text { Age group } \\
\text { (years) }\end{array}$} & Genotype 1 & Genotype 3 & Genotype 4 \\
\hline & n (\%) & n (\%) & $\mathrm{n}(\%)$ \\
\hline$<25$ & $35(89.7)$ & $1(2.6)$ & $3(7.7)$ \\
\hline $25-34$ & $74(81.3)$ & $17(18.7)$ & $0(0.0)$ \\
\hline$>34$ & $38(55.9)$ & $27(39.7)$ & $3(4 \cdot 4)$ \\
\hline Exact $p$ & $<0.001^{a}$ & $<0.001^{a}$ & 0.021 \\
\hline $\begin{array}{l}\text { Duration of drug } \\
\text { injection use (years) }\end{array}$ & n (\%) & n (\%) & n (\%) \\
\hline$<5$ & $33(94 \cdot 3)$ & $1(2.9)$ & $1(2.9)$ \\
\hline$\geq 5$ & $111(69.8)$ & $43(27.0)$ & $5(3.1)$ \\
\hline Unknown & $3(75.0)$ & $1(25.0)$ & $0(0.0)$ \\
\hline Exact $p$ & 0.002 & 0.001 & 1.000 \\
\hline
\end{tabular}

a with strong evidence of linear trend.

the provincial towns than in Budapest. This observation suggests that PWID communities with different genotype frequencies exist in Hungary.

Three of the four HCV genotype 4-infected PWID outside Budapest were residents of the same town, Veszprém (ca. 64,000 inhabitants). Only four PWID in Veszprém were found to be positive for HCV: three of them carried genotype 4 and one genotype 3. Although few viruses were genotyped, our data suggested a possible epidemic of HCV genotype 4 among PWID in Veszprém. In contrast, all five HCV RNA-positive individuals detected in the general population of Veszprém carried genotype 1. HCV genotype 4 is often associated with drug injection use in Europe [23].

A shorter duration of drug injection use was found to correlate with a higher prevalence of genotype 1 and a lower prevalence of genotype 3. The prevalence of genotype 1 was significantly higher in the youngest age group ( $\$ 25$ years old). Younger PWID are most likely to present with a more recently acquired infection. These data suggest that the prevalence of HCV genotypes may drift towards genotype 1 in the future among Hungarian PWID. In contrast, the genotype recently emerging among PWID in the Czech Republic is genotype 3 [22]. No other publication was found about changes in genotype distributions in other neighbouring countries.

The correlation between the HCV genotype and the type of drug injected was not confirmed after adjusting the data to the duration of injection drug use and geographical distribution. Consequently, the correlation between opiate use and infection with genotype 3 was probably due to an association of opiate use with the users' older age and the duration of drug use.

The prevalence of different genotypes that Gervain et al. observed in the general population in Hungary was similar to our results [5]. Importantly, none of the individuals in our study was infected with more than one genotype or subtype, either in the general population or among the PWID, whereas Gervain et al. did identify mixed infections [5]. This difference might be due to the use of different versions of the LIPA kit for subtyping.

Phylogenetic analysis of the $\mathrm{NS}_{5} \mathrm{~B}$ nucleotide sequences of the genotype 3 viruses confirmed previous findings that genotype 3 HCVs from PWID in different geographical areas do not form well-defined clades [4]. However, some clear sub-clusters with strong bootstrap values were apparent in the Hungarian sequences, suggesting that the individuals in the sub-clusters were infected by each other, probably through unsafe practices of drug injection.

The limitations of our study include that we had HCV PCR-positive samples only from six of the seven Statistical Regions. Also, when genotyping is carried out by sequencing a region of the 5' UTR, genotypes 1 and 6 are not distinguishable. However, genotype 6 is prevalent only in the area of Hong Kong [3] and, of the 45,462 sequences in the HCV sequence database for Europe, only six strains belonged to genotype 6 [24]. Moreover, 43 of the 49 type $1 / 6$ viruses from PWID subtyped by hybridisation in this study were of genotype 1 , and none of them were shown to be of genotype 6 . Further limitations are that only 49 of the 147 genotype 1 HCV of PWID were subtyped, and that we did 
not sequence the whole genomes, thus recombinant viruses may not have been recognised if they were present, and may have been misclassified.

The determination of HCV genotypes in PWID is of more than epidemiological significance. More than $95 \%$ of the HCV carriers in the Hungarian general population are infected with HCV genotype 1. The current National Treatment Protocol specifies that genotyping is not compulsory before treatment and is strongly recommended only for foreign nationals living in Hungary [25]. Our findings lead us to propose that the Treatment Protocol should be modified to include Hungarian PWID in addition to foreigners. Since genotype 3 is relatively susceptible to treatment and is common among PWID, it is possible that the shorter treatment time (24 versus 48 weeks) and the higher cure rate ( $>75 \%$ versus ca. $45 \%$ ) can help convince people who have ever injected drugs to accept and complete a course of treatment, and would also reduce costs. We assume that genotyping and subtyping will remain or become a more important tool for individualised therapy in the future in view of upcoming treatments with direct acting agents [26].

\section{Acknowledgements}

This study was supported by DIAGNOSTICUM Inc., Hungary and the Hungarian Research Fund grant OTKA-81454 (A. Pár). The authors are grateful to Prof. Éva Gönczöl for her critical reading of the manuscript. We thank Judit Krisztina Horváth MD, MSc (Office of the Chief Medical Officer of State in Hungary) for help with statistical analysis. The work of those who collected the samples, and the excellent technical assistance of the staff at the NCE are highly appreciated.
References

1. Simmonds $P$, Bukh J, Combet C, Deléage G, Enomoto N, Feinstone $S$, et al. Consensus proposals for a unified system of nomenclature of hepatitis $C$ virus genotypes. Hepatology. 2005;42(4):962-73.

http://dx.doi.org/10.1002/hep.20819

PMid:16149085

2. Rosen HR. Clinical practice. Chronic hepatitis $\mathrm{C}$ infection. $\mathrm{N}$ Engl J Med. 2011;364(25):2429-38.

http://dx.doi.org/10.1056/NEJMcp1006613 PMid:21696309

3. Noorali S, Pace DG, Bagasra O. Of lives and livers: emerging responses to the hepatitis $C$ virus. J Infect Dev Ctries. 2011;5(1):1-17. PMid:21330735

4. Morice Y, Cantaloube JF, Beaucourt S, Barbotte L, De Gendt $\mathrm{S}$, Goncales FL, et al. Molecular epidemiology of hepatitis $C$ virus subtype $3 a$ in injecting drug users. J Med Virol. 2006;78(10):1296-303.

http://dx.doi.org/10.1002/jmv.20692 PMid:16927280

5. Gervain J, Simon Jr G, Simon J; Hungarian Viral Hepatitis Group. Genotype distribution of hepatitis C virus in the Hungarian population with chronic viral hepatitis C Eur J Gastroenterol Hepatol. 2003;15(4):449-50.

http://dx.doi.org/10.1097/00042737-200304000-00021 PMid:12655271

6. Müller Z, Deák J, Ross RS, Nagy E, Kovács L, Roggendorf M, et al. Hepatitis C virus genotypes in Hungarian and Austrian patients with chronic hepatitis C. J Clin Virol. 2003;26(3):295300 .

http://dx.doi.org/10.1016/S1386-6532(02)00045-8

7. European Centre for Disease Prevention and Control (ECDC). Annual Epidemiological Report 2011. Reporting on 2009 surveillance data and 2010 epidemic intelligence data. Stockholm: ECDC; 2011. Available from: http://ecdc. europa.eu/en/publications/Publications/1111_SUR_Annual Epidemiological_Report_on_Communicable_Diseases_in_ Europe.pdf

8. Bozsonyi K, Csesztregi T, Dudás M, Horváth GC, Keller É, Koós T, et al. 2010 National Report to the EMCDDA by the Reitox National Focal Point. Hungary. New developments, trends and in-depth information on selected issues. Lisbon: European Monitoring Centre for Drugs and Drug Addiction (EMCDDA). [Accessed 3 Dec 2012]. Available from: http://drogfokuszpont. hu/wp-content/uploads/nr_10_en.pdf

9. Csesztregi T, Dudás M, Felvinczi K, Horváth GC, Huszár L, Koós T, et al. 2011 National Report to the EMCDDA by the Reitox National Focal Point. Hungary. New developments, trends and in-depth information on selected issues. Lisbon: European Monitoring Centre for Drugs and Drug Addiction (EMCDDA). [Accessed 3 Dec 2012]. Available from: http://drogfokuszpont. hu/wp-content/uploads/national_report_2011_hungary.pdf

10. Bánhegyi D, Böröcz K, Kertész A, Melles M, Milassin M, Pechó Z, et al. Tájékoztató a betegellátás során a vérrel és testváladékokkal terjedő vírusfertőzések megelőzéséről. Epinfo. 2003;10(2. különszám):1-39.

11. Tresó B, Barcsay E, Tarján A, Horváth G, Dencs A, Hettmann A, et al. Prevalence and Correlates of HCV, HVB, and HIV Infection among Prison Inmates and Staff, Hungary. J Urban Health. 2012;89(1):108-16

http://dx.doi.org/10.1007/s11524-011-9626-x PMid:22143408 PMCid:PMC3284587

12. Dencs A, Hettmann A, Martyin T, Jekkel C, Bányai T, Takács $M$. Phylogenetic investigation of nosocomial transmission of hepatitis C virus in an oncology ward. J Med Virol. 2011;83(3):428-36.

http://dx.doi.org/10.1002/jmv.21983

PMid:21264863

13. Cochrane A, Searle B, Hardie A, Robertson R, Delahooke $T$, Cameron $S$, et al. A genetic analysis of hepatitis $C$ virus transmission between injection drug users. J Infect Dis. 2002;186(9):1212-21.

http://dx.doi.org/10.1086/344314

PMid:12402190

14. Hickman M, McDonald T, Judd A, Nichols T, Hope V, Skidmore $\mathrm{S}$, et al. Increasing the uptake of hepatitis $\mathrm{C}$ virus testing among injecting drug users in specialist drug treatment and prison settings by using dried blood spots for diagnostic testing: a cluster randomized controlled trial. J Viral Hepat. 2008;15(4):250-4.

http://dx.doi.org/10.1111/j.1365-2893.2007.00937.x

PMid:18086182

15. Abe K, Konomi N. Hepatitis C virus RNA in dried serum spotted onto filter paper is stable at room temperature. J Clin 
Microbiol. 1998 Oct;36(10):3070-2.

PMid:9738072 PMCid:PMC105116

16. Hope VD, Hickman M, Ngui SL, Jones S, Telfer M, Bizzarri $M$, et al. Measuring the incidence, prevalence and genetic relatedness of hepatitis $C$ infections among a community recruited sample of injecting drug users, using dried blood spots. J Viral Hepat. 2011;18(4):262-70.

http://dx.doi.org/10.1111/j.1365-2893.2010.01297.x

PMid:20456636

17. Mahfoud Z, Kassak K, Kreidieh K, Shamra S, Ramia S.

Distribution of hepatitis C virus genotypes among injecting drug users in Lebanon. Virol J. 2010;7:96.

http://dx.doi.org/10.1186/1743-422X-7-96

PMid:20465784 PMCid:PMC2885342

18. Tuaillon E, Mondain AM, Meroueh F, Ottomani L, Picot MC, Nagot N, et al. Dried blood spot for hepatitis C virus serology and molecular testing. Hepatology. 2010;51(3):752-8. PMid:20043287

19. Pybus OG, Cochrane A, Holmes EC, Simmonds P. The hepatitis $C$ virus epidemic among injecting drug users. Infect Genet Evol. 2005;5(2):131-9.

http://dx.doi.org/10.1016/j.meegid.2004.08.001

PMid:15639745

20. Seme K, Poljak M, Lesnicar G, Brinovec V, Stepec S, Koren S. Distribution of hepatitis C virus genotypes in Slovenia. Scand J Infect Dis. 1997;29(1):29-31.

http://dx.doi.org/10.3109/00365549709008660 PMid:9112294

21. Vince A, Iscić-Bes J, Zidovec Lepej S, Baća-Vrakela I, Bradarić $\mathrm{N}$, Kurelac I, et al. Distribution of hepatitis $C$ virus genotypes in Croatia--a 10 year retrospective study of four geographic regions. Coll Antropol. 2006;30 Suppl 2:139-43. PMid:17508487

22. Krekulová L, Rehák V, Strunecký O, Nēmecek V. [Current situation and trends in the hepatitis C virus genotype distribution among injecting drug users in the Czech Republic]. Epidemiol Mikrobiol Imunol. 2009;58(2):84-9. Czech. PMid:19526922

23. Chlabicz S, Flisiak R, Lapinski TW, Kowalczuk O, WiercinskaDrapalo A, Pytel-Krolczuk B, et al. Epidemiological features of patients infected with HCV genotype 4 in Poland: Epidemiology of HCV genotype 4 in Poland. Hepat Mon. 2011;11(3):191-4. PMid:22087142 PMCid:PMC3206688

24. HCV sequence database. [Accessed 28 Feb 2012]. Available from: http://hcv.lanl.gov/content/sequence/HCV/ToolsOutline. html

25. Infektológiai Szakmai Kollégium. [Infectious Diseases Advisory Board]. A Nemzeti Erőforrás Minisztérium szakmai protokollja a C hepatitis antivirális kezeléséről. [The Ministry of National Resources' professional protocol for hepatitis C antiviral treatment]. Egészségügyi Közlöny. [Official Bulletin of the Ministry of National Resources in Hungary]. 2011;61(7):1393-401.

26. Kronenberger B, Zeuzem S. New developments in HCV therapy. J Viral Hepat. 2012;19 Suppl 1:48-51.

http://dx.doi.org/10.1111/j.1365-2893.2011.01526.x

PMid:22233414 XxX 